\title{
Bridging the Gap between Work and Education in Vocational Education and Training. A study of Norwegian Apprenticeship Training Offices and E-portfolio Systems
}

\author{
Hage Nore \\ Oslo and Akershus University College of Applied Sciences \\ Faculty of Education and International Studies Department \\ of Vocational Teacher Education \\ PO box 4 St. Olavs plass, NO-0130 Oslo, Norway \\ Email: haege.nore@hioa.no \\ Leif Christian Lahn \\ University of Oslo/Oslo and Akershus University College of Applied Sciences \\ Faculty of Education and International Studies Department \\ of Vocational Teacher Education \\ PO box 4 St. Olavs plass, NO-0130 Oslo, Norway \\ Email: 1.c.lahn@iped.uio.no
}

\begin{abstract}
This article explores the effect that the use of e-portfolios initiated and organized by apprenticeship training offices has had on the learning processes and assessment practices of apprentices in Norwegian vocational education and training. Although these intermediate structures have the potential to bridge the gap between work and education, they seem to maintain a system of two parallel learning arenas. However, the article summarizes the innovative effects of these transformations as supportive structures for expansive apprenticeship. The study is based on data from a national project on quality assessment, which is supported by documentary evidence from e-portfolios in three different trades: plumbing, industrial mechanics and sales.
\end{abstract}

Keywords: apprenticeship, boundary-crossing, e-portfolios, training offices/ agencies, innovation. 


\section{Introduction}

In the debates about vocational education and training (VET), the interaction between school and work is a recurrent theme. A number of studies have demonstrated how apprentices struggle with making school knowledge relevant for their practice (Finch et al., 2007) and vice versa - making their work-based knowledge an asset in educational contexts (Akkerman and Bakker, 2012). There is a growing recognition among scholars and policy makers that a mutual transfer needs to be supported by institutional and/or technological systems that mediate the relationship between school and work, and that generate boundary crossing (Tuomi-Gröhn and Engeström, 2003). From an international comparative perspective, such intermediate structures differ depending on key characteristics of the national VET systems - notably the way they organize the school - work relationship (Rauner and MacLean, 2009).

In this article, we use data from a study of Norwegian apprenticeship training offices and e-portfolio systems to discuss how such intermediate structures support boundary crossing in apprenticeship. First, we will position the training offices in the Norwegian VET system but devote a short section of our text to similar institutions in other countries. The implementation of e-portfolios in this new organizational construction will be analyzed using a conceptual framework derived from the literature on cognitive apprenticeship (Ghefaili, 2003). On the basis of our study, we will ask whether the apprenticeship training offices and their e-portfolio systems are able to bridge learning environments, and to what extent they support the development of higher-order skills such as understanding and learning to learn in their work contexts among the apprentices. A final discussion revolves around contesting ideas about the integration of school and work in apprenticeship systems.

\section{Apprenticeship Training Offices in the Norwegian VET System}

Vocational education and training (VET) in Norway is an alternating dual system conducted in both schools and enterprises. The main model is two years as a student in upper secondary school followed by two years of apprenticeship in a public or private training establishment ${ }^{1}$ approved by the educational authorities at the county level. After in-company training of apprentices became part of the formal education system in 1994, a number of apprenticeship training offices were established. The offices are approved as training establishments, but are owned and driven by a community of companies. Each member company is also individually approved as a training establishment, but it is the offices that receive state funding. Offices will distribute part of the funds to the companies according to the division of labor between the office and the companies. Moreover, apprenticeship training offices are either trade-specific or interdisciplinary, and their tasks are to:

- recruit apprentices and training enterprises

- network with enterprises, schools and branch organizations

- establish quality systems, including e-portfolios

- follow up apprentices and secure that they are trained in one or more of the member offices

- deliver courses and training material

- organize sessions for apprentices

- follow up and secure training of the trainers

1 Company approved for training apprentices. 
In the Norwegian VET system, the apprenticeship contract is defined between the apprentice and the apprenticeship training office, while the training is primarily company-based. Today, $75-80 \%$ of the apprentices have training contracts with a training office, in addition to their temporary employment contract with a company (Deichman-Sørensen, 2007; Michelsen and Høst, 2013). Hence, apprenticeship training offices play an essential role in the Norwegian VET system, and this institution has received growing international attention (Helms Jørgensen and Juul, 2007). To help support their work, the offices organize various networks (Havn et al., 2009; Høst and Michelsen, 2014):

- between companies as owners and members of the office

- between member companies and schools on a local/regional level

- between apprenticeship training offices (cross-sectional), together with representatives from educational authorities at the county level

- between apprenticeship training offices and the branch organizations on a national level

- between apprenticeship training offices and e-portfolio system developers

It has been suggested that they represent a new structure that radically influences the work-based learning characteristic of traditional apprenticeship regimes and the ideology of master learning.

A Norwegian educational reform in 2006 (the Knowledge Promotion), introduced common competence goals for the school-based and company-based part of VET. The trainers are expected to develop local plans, content and activities based on a state-regulated curriculum, and to secure that the objectives are realized through holistic assessment schemes and practices. This is what Rauner, Wittig and Deitmer (2010) call an integrated output model, and there seems to be a tension between the old master learning and such a model, which can also serve as a driver for innovative apprenticeship (Grollman and Rauner, 2007). Do intermediate structures such as the apprenticeship training offices and their e-portfolio systems generate a new parallel learning structure, and if so, how are integrated goals achieved and to what extent do they support the learning trajectories of apprentices?

Although the system with apprenticeship training offices is institutionalized in Norwegian VET and its specific dual arrangement, similar structures are to be found in other countries. For example, in Australia there are AMAs: Apprenticeship \& Traineeship Services contracted by the Australian Government. The AMAs aim to support both the employers and the apprentices to help secure the quality of training. The employers receive access to business consultants, who guide them through the paperwork and develop a training strategy. The AMAs deliver theory training and other group training activities in cooperation with registered training organizations. In UK there is a growing number of Apprenticeship Training Agencies (ATA), which are separate legal entities established to recruit and employ apprentices and hire them out to host employers, particularly in small enterprises. The ATAs have the full responsibility for the welfare, health and safety, training and employment of the apprentices. The host employer also pays the ATA a fee for the apprentice's services, based on the apprentice's wage and any training costs, whereas AMAs are approved according to a framework by the governmental Skills Funding Agency. Although the national 
systems in which these agencies operate are very different from the Norwegian context, they have institutionalized similar functions as an intermediating construct between apprenticeship and formal schooling.

A common aim of all the agencies seems to be high-quality education and training. In contrast, the fact that training responsibility is outsourced from the companies requires an increased awareness of the distance between work, education and training. Hence, we explore the assumption that e-portfolios can bridge the gap between work-based learning and a more systematic education and training.

\section{E-portfolios as Boundary Objects for the Development of Cognitive Apprenticeship?}

E-learning and networked learning environments have claimed to bridge the gap between school and work in VET (MacLean and Wilson, 2009). The so-called eportfolios could be used for the documentation and assessment of prior learning and experience, but also as a technology for stimulating the articulation and reflection of knowledge, experience and learning (Attwell and Pumilia, 2007). In the latter case, the objective to be achieved is consonant with the principles of cognitive apprenticeship, which state that practitioners should be able not only to have knowledge of what to do and how to do it, but also the why behind task performance. We want to add that apprentices' modern working life needs to learn to learn, which often involves expertise in boundary crossing - that is to move between dissimilar practices, to master transitions and to change critical situations in productive ways (Akkerman and Bakker, 2011). Thus, we are talking about processes that transfer back and forth between work and education, and ones that may be near (immediate and specific) or far (delayed and general), see Aarkrog 2011.

E-portfolio could be characterized as a boundary object in the present discussion. Thereby we want to emphasize that such objects mediate boundaries by both including the two sides and keeping them apart (Akkermann and Bakker, 2011). Another dimension is brought to the fore by Tuomi-Gröhn, Engeström and Young (2003) when they connect the words "object" and "objective". Boundary objects should refer to systems that have a contradictory but shared objective. As mentioned above, e-portfolios may function as instruments for documentation and control or reflection and development - depending on the institutional context and the policies in the field.

Studies have demonstrated that apprentices and practitioners find it difficult to translate between knowledge situated in work and in educational contexts (Eraut, 2002). Such processes need to be facilitated by specific training schemes and/or intermediate structures such as the Norwegian apprenticeship training offices. Similar conclusions have been made in international reviews of VET (Onstenk, 2010), so when we use the concept "boundary object", it refers to a socio-technical system in which tools are embedded within an organizational and cultural context.

The Norwegian apprenticeship training offices have only recently implemented e-portfolios as a tool for mediating experiences and feedback between apprentices, the training establishment and the training offices, although its use has spread rapidly after a trial period with skepticism among key stakeholders. At present, the different e-portfolio systems are versions of learning management systems (LMS) and are basically targeting the learning outcomes of 
the national curricula. A study by Høst et al. (2012) has identified a tension between the use of these systems to document the quality of work performance on the one side and to document the achievement of apprentices according to curricular objectives on the other. Additionally, branch organizations and trade unions differ radically in what they expect from the systems - ranging from the technical trades that emphasize their documentary function to the prioritization of reflection by the associations of health-care workers. Consequently, the question of parallel and integrated structures has to include these contingencies.

\section{$4 \quad$ Research Method}

The research to be discussed here is part of a longitudinal qualitative study that follows 115 students from the second year in school to their trade or journeyman certificate two (and a half) years later.

A strategic quota sampling was made in three different trades: plumbing, industrial mechanics and sales. Plumbing have a long tradition, a strong identity and formal authorization schemes that clearly influence their apprenticeship. Industrial mechanics and similar vocations undergo continuous changes and recruit from a wide range of workplaces in larger companies. Sales does not have the same tradition for skilled workers, and the formal education and training of salespersons is relatively new in Norwegian VET. Whereas the apprenticeship training offices of the plumbing are trade-specific, the training offices for the industrial mechanics possess a wide range of technical and industrial trades. Training offices for sales are often interdisciplinary, e.g. together with cooks, waiters and receptionists.

The sample also represents three counties across Norway, with different occupational cultures and training traditions. One county has traditions linked to forestry and agriculture, with a relatively low educational level. Another county has traditions dating back to hydropower and energy-intensive industry, as well as a high number of skilled workers and engineers, while the third county represents the oil industry and their subcontractors. The interest for VET and the number of skilled workers are high, as is the general educational level.

The cross-cutting theme of the broader project is on quality assessment in VET funded by The Norwegian Directorate for Education and Training (Høst, 2012). It examines the actual quality in different areas of Norwegian VET. Another aspect in the project is how different stakeholders are dealing with quality improvement, with the project consisting of four sub-themes: 1) Learning environments, completion and dropout, 2) content and assessment practices, 3) quality assurance, quality management and quality assessment, and 4) VET as a gateway to employment.

This article is based on research related to sub-theme 2, which concentrates on how training establishments and training offices work together on defining content, implement curricula and build assessment practices for apprentices in the three different trades. This article draws on the second phase of the larger longitudinal study, after one and a half years of apprenticeship. The analyses of training offices' work and their role as mediators for apprentices and training enterprises are based on semi-structured qualitative interviews with approximately 50 apprentices, 40 incompany trainers and 11 training offices. All interviews were recorded, transcribed and thematically analyzed, and supported by field notes.

The interview data were validated and elaborated by documentary evidence from e-portfolios, local training plans, task descriptions, test tasks, assessment schemes and other reports given to the training offices by the apprentices or the 
trainers. The data was analyzed according to how the different respondents use the curricula, how they plan and organize content and progression in learning processes and how they establish assessment practices.

The extensive use of e-portfolios in the apprenticeship opened up new dimensions in the study, including the role of the system developers, the cooperation between the training offices and the system developers, the cooperation between the training offices and the branch organizations, and the impact of using e-portfolios on the apprentices' learning processes.

\section{E-portfolio for What and for Whom}

All respondents referred to the increasing use of e-portfolios as a tool for quality assurance and communication between the apprentice, the training establishment and the training office. With e-portfolios, the training offices have claimed to track the apprentices' learning outcomes according to the competence goals in the curriculum and their documentation of learning tasks in the training establishment. On the other hand, the data showed a variable use of e-portfolios by the apprentices. Most of the apprentices claimed that their daily work was more important than eportfolios, and filled in the portfolios just in time for half-year assessment conversations with their trainer and the training office, though sales was the exception. Here, the apprentices continuously worked with learning tasks defined and documented in the e-portfolio and assessed by the training office. At the end of the apprenticeship, e-portfolios function as a tool for gap-analyses, which are the documented achievements in the apprenticeship period compared with the curricular learning objectives. We did not find any examples of e-portfolios used as a collaborative medium for the exchange of experiences between apprentices, or between apprentices and vocational experts. The e-portfolios studied were used to target the individual performances of apprentices. In all three trades, the incompany trainers reported that they sometimes looked into the records of the LMS in order to prepare for meetings with the training offices. Thus, the accountancy function of the system was crucial as the quality of the apprenticeship, which was formalized through the companies' membership in an apprenticeship training office, along with these offices' monitoring of the e-portfolios. It seems safe to conclude that at present, these systems were loosely coupled to the in-company training practices. In nearly all of the apprenticeship training offices, their instrumental use of the LMS was justified as an effective way of meeting the report requirements from the educational authorities at the county level. Høst and Michelsen (2014) describe the apprenticeship training offices as an increasingly important actor that positions itself between the training establishment and the county officials.

Although the e-portfolios/LMS primarily supported the monitoring of the apprenticeships in relation to curricular norms, they certainly had an impact on both the design of educational provisions and on the learning environment of the apprentices. For example, apprentices used much of their training time in sales to work on and document tasks defined in the tool, and not on everyday issues that would be relevant for the in-company trainers and work-based learning. In plumbing, they were expected to take theory tests that were delivered, performed and scored in the e-portfolio/LMS. The apprentices in industrial mechanics could use these systems as portals and have access to e-learning programs and specific courses in the mechanics of materials or health and security developed by an industrial branch organization. The fulfillment of e-learning modules by the apprentices was automatically registered in the LMS, and the tasks to be reported 
and the skills tested online were validated in relation to the competence goals in the curricula, which again underscores the importance of the LMS as an accounting device for educational quality.

One type of practice that could make the e-portfolios/LMS have the character of a boundary object was when they were used in assessment sessions with apprentices, in-company trainers and apprenticeship training offices. This communication focused not only on issues such as the achievement of learning outcomes, progression and gap analysis in relation to curricular goals, but also on the quality of in-company practice and counselling. The latter points to a potential for these online systems and the new organizational structures to bring curricula and the formal educational system closer to the in-company training.

\section{Two Parallel Learning Systems}

From the data presented above, we can conclude that the present use of the eportfolio/LSM within the organizational framework of the apprenticeship training offices does not support boundary crossing and the development of cognitive apprenticeship. In fact, the technology may have displaced the attention and energy of the participants in the apprenticeship from a focus on in-company training to the fulfillment of curricular goals and their online transmission. For this reason, we could talk about two parallel learning systems with the characteristics shown in Table 1. As described in the left column, most apprentices and trainers in our study reported a traditional master and situated learning process. Apprentices perform simple tasks connected to ongoing work, learning what they do in a community of practice and through discussions with experienced workers and customers. Documentation is a part of most jobs, and is included in internal quality systems. Feedback processes are weak, although everything is fine as long as you do not hear anything, or as long as the result is in accordance with the required quality. Trainers guide apprentices according to the task performance.

However, the apprenticeship training offices describes a parallel learning system such as that in the right column in Table 1. They expect apprentices to focus more on learning and learning outcomes according to curricular norms. In addition to work-based learning, the offices and licensed training providers offer apprentices specific courses, both on-site and online, and train apprentices to document learning outcomes and progression in the e-portfolios. Together with incompany trainers, apprentices receive feedback from the training office through the e-portfolios and through half-year assessment conversations. For the apprentices, the learning arena may become a hybrid, albeit a fragmented one, consisting of daily work, online courses, company-internal courses, external courses, specific training tasks, e-portfolios and apprenticeship gatherings. The system for feedback and guidance steers vocational learning and personal progression towards the fulfillment of the Norwegian competence goals for each trade. Structurally it therefore supports curriculum-based learning. Recent studies (Høst and Michelsen, 2014) of the formal position of the apprenticeship training offices indicate that they have strengthened their role in the Norwegian VET sector. We want to add that the implementation of the e-portfolio/LMS has also boosted this development. Within the framework of a national quality system, the transfer of these monitoring tasks from the county officials to the training offices represent a decentralization of operative responsibility and a stronger link to the training establishments. 
Table 1: Two parallel learning systems

\begin{tabular}{|l|l|}
\hline Work-based learning & Curriculum-based learning \\
\hline Performance & Learning outcomes \\
\hline Situated learning & Hybrid learning arena \\
\hline $\begin{array}{l}\text { Continuous discussions with colleagues, } \\
\text { customers and trainers }\end{array}$ & $\begin{array}{l}\text { Follow-up discussions and half-year } \\
\text { assessment conversations with } \\
\text { trainers and training offices }\end{array}$ \\
\hline International documentation & E-portfolios \\
\hline $\begin{array}{l}\text { Feedback on performance according to } \\
\text { quality standards and recommendations }\end{array}$ & $\begin{array}{l}\text { Feedback on vocational learning and } \\
\text { personal progression according to } \\
\text { curricula }\end{array}$ \\
\hline Trainers/mentors & $\begin{array}{l}\text { Training offices/apprentice } \\
\text { gatherings }\end{array}$ \\
\hline
\end{tabular}

The dichotomy presented in Table 1 may exaggerate differences in the two structures, though by contrast it also has some evidential backing in other studies, e.g. the distinction made by Kirpal (2010) between training schemes that guide performance and those that guide learning processes. In such contexts, performance goals may be contrasted with learning goals (Dweck, 1986). The parallel structure does not seem to support cognitive apprenticeship as pointed out above, and there are very few instances in our material where apprentices use the online system for feedback and reflection on the basis of authentic work experiences. Given the situated and implicit character of such knowledge (Akkerman and Bakker, 2012), one should expect that an articulation of these skills in a learning arena requires a focused attention and specific strategies on the part of instructors. The apprentice sessions or workshops could prepare the ground for such processes, but were not integrated within the e-portfolio/LSM. Of course, given the lack of opportunities for sustainable reflection and the elaboration of work-based experiences, this set-up would not contribute in any decisive way to the apprentices' learning to learn. We need to add here that we did not study the use of the online systems in the field of health care and social work, in which national vocational bodies have advocated the use of the e-portfolio and portfolio systems in general as a tool for reflection on practice.

In sum, the e-portfolios/LSMs were meant to bridge the gap between the everyday learning of apprentices and the curricula defined by the national competence goals. Nonetheless, a parallel learning structure persists and to some extent, the division has been deepened. Not only is the translation from work to a reflective arena both on- and off-line rendered difficult. Theoretical understanding and questions of "why" may not be brought into contact with practice and become an inert knowledge that is reproduced in tests and examinations (Bereiter and Scardemalia, 1985), they have little relevance for the apprentices' vocational development. Likewise, if too much attention is devoted to the apprentices' initiation into a vocational culture and community of practice, such an immersion complicates a progression according to curricula standards (Grollmann and Rauner, 2007).

These conclusions need to be problematized, since the implementation of the e-portfolios/LMSs and the expanded role of the apprenticeship training offices have a contradictory character. These elements have brought the national monitoring and review tasks closer to the in-company training, and thereby the 
potential for boundary crossing in a productive sense is boosted. It also needs to be added that as pointed out by Engeström and Toiviainen (2010), integration between two systems is a laborious process, which among other things, requires the adjustment of norms, rules and division of labor. In-company training is obviously influenced by the outsourcing of services to the training offices and their electronic management and quality systems, but there is a need to evaluate the concerted effects of the different parts on the apprenticeship system. In the next section, we will discuss whether and in what way the apprenticeship training offices can become innovators in Norwegian VET.

\section{$7 \quad$ Training Offices as Innovators in an Expansive Apprenticeship?}

In our earlier reference to cognitive apprenticeship, we emphasized that this concept should include more than just an intellectual upskilling. The turbulence of modern societies requires that apprentices acquire transformative competence and a high degree of self-design (Guile and Okumoto, 2008). Although there is a consensus in the literature that boundary crossing between work and education will promote these qualities, scholars do not share an understanding of how these sectors should be integrated, nor of the need for intermediating structures. Aarkrog (2005) claims that the tension between the parallel learning systems represents a dynamic force that may generate innovations. Our review of experiences with the Norwegian apprenticeship training offices has concluded that the separation of the two arenas for apprenticeship persists, but at the same time we want to highlight several factors that could be the sources for innovative practices: The explication of work skills, hybrid qualifications, a closer involvement with the training companies and their vocational culture, on- and off-line sessions with apprentices and networking among apprenticeship training offices.

- Explication of work skills. The apprentices' logs of their performance are usually not very elaborate. As such, these exercises in written format would have a moderate influence on their literacy skills. However, the apprentices may become more challenged at explicating what they do, and the eportfolio/LMS should help facilitate access to the "theoretical stuff". For example, in plumbing they were asked to solve online cases that required an understanding of physics and mathematical calculations. In sales, the apprentices also had to work with tasks that were quite authentic and involved concepts in economics and marketing. Given that these processes are linked to the work experiences of the apprentices, we could see the contours of a system for innovative, expansive apprenticeship (Fuller and Unwin, 2010).

- Hybrid qualifications (Davey and Fuller, 2013). Another aspect of this conceptual scaffolding embedded in the e-portfolio/LMS and the services of the training offices is that they could qualify the apprentices for hybrid tracks, meaning that the systems would support both the trade examination and the admittance to a tertiary education. Many of the apprentices we interviewed envisaged such careers, which were also distinct for each of the trades. In sales, the option was higher education, in plumbing a technical college or master craftsman, while in industrial mechanics a higher education in engineering and supplementing trade certificates were frequently mentioned. 
At the present time, the responsibility for such preparations was not within the scope of the training offices, but could be an area for expansion.

- Closer involvement with training companies. As previously mentioned, the intermediate role of the training offices between the companies, schools and the county educational authorities had the effect that the former were given a strong monitoring and reviewing authority in the Norwegian VET system. Still, our data indicate that local closeness, a stronger human resource orientation among the staff members and the e-portfolio/LMS helped to facilitate the integration of these "formal" tasks with the guidance of the apprentices and sometimes also in-company trainers.

- On- and off-line sessions with apprentices. Our data confirmed findings from international studies (Akkerman and Bakker, 2012) that demonstrated the importance of sessions with apprentices in order to develop a more general understanding of what they do and how they learn. Several training offices wanted to give a higher priority to such activities - possibly also as provisions for online meetings.

- Networking among apprenticeship training offices. As mentioned above, the training offices have been active in establishing new networks between different actors in the Norwegian VET. These constructions may stimulate and even change educational practices and develop common quality standards and tools connected to curricula, educational design, relevant tasks and assessment procedures (Veugelers and O'Hair, 2005). Our study shows that these networks have features that are trade-specific. In plumbing, there is a strong identity in the trade, and the branch organizations are very active participants. The industrial networks cover a wide range of trades within the technical and industrial sector, addressing themes of broader and more interdisciplinary interest such as competence development for the sector in the face of international competition. The initiatives for the establishment of networks in sales are fewer, thus reflecting the embryologic character of this trade.

These points could summarize the potential of the Norwegian training offices and their e-portfolio/LMS to be innovators in the VET system. It should be noted that the arrangement with apprenticeship training offices and e-portfolios are recent occurrences, and that the processes pointed to above often need some time to emerge and stabilize.

\section{Conclusions}

The evolution of the Norwegian training offices is a rather silent and gradual process, which has had a major impact on the apprenticeship system without ever being proclaimed as a national reform in VET. However, the training offices organize almost all apprentices, and although their variants of e-portfolio/LMS represent a rather trivial technology, this element is important for two reasons: (1) This intermediary structure has obtained a central position in Norwegian VET, and (2) It involves a large majority of the participants in the apprenticeship system. To repeat, we are speaking of an institution that is quite new. In addition, the technology needs to be developed and attuned to the needs of a new generation of apprentices who are familiar with social networking and learning on the web (Tapscott, 2009; Pedro, 2006; Brown, 2008). For trainers in companies and in the 
training offices, there is also a challenge to become designers of online learning environments (Hauge et al., 2007). One should therefore expect the boundary crossing announced above to be a rather long and thorny process.

Is the arrangement with training offices a solution to the persisting gap between work and education in dual system apprentices? It is conceivable that an intermediate structure is needed that has the potential to bridge the two parallel learning structures in ways that could help to promote cognitive apprenticeship? Even so, it also represents an institutional displacement of the accounting and quality assurance tasks that formerly were effectuated by the counties' educational authorities. At present, we do not see the full range of this transformation.

Compared with similar structures on the international scene, the training offices in Norway are closely linked to companies and work-based learning through the companies' ownership of the offices, and not as a governmental regulation and counseling to companies and apprentices. The companies are still an important part of the tripartite system that forms VET in Norway, and the training offices have direct access to both work-based learning and the county educational authorities. More comparative research should be done in order to make us understand the role of these intermediate constructions in different VET-systems. 


\section{References}

Akkerman, S. F., \& Bakker, A. (2012). Crossing boundaries between school and work during apprenticeships. Vocations and Learning, 5(2), pp. 153-173.

Akkerman, S.F. \& Bakker, A. (2011). Boundary crossing and boundary objects. Review of Educational Research, 81(2), pp. 132-169

Attwell, G., \& Pumilia, P. (2007). The New Pedagogy of Open Content: Bringing Together Production, Knowledge, Development, and Learning. Data Science Journal, Vol. 6, April 2007.

Aarkrog, V. (2011). A taxonomy for teaching transfer skills in the Danish VET system. Nordic journal of vocational education and training, 1, 1, pp. 1-13

Aarkrog, V. (2005). Learning in the workplace and the significance of schoolbased education: a study of learning in a Danish vocational education and training programme. International journal of lifelong education, 24, 2, pp. 137-147.

Bereiter, C. \& Scardamalia, M. (1985). Cognitive coping strategies and the problem of "inert" knowledge. Thinking and learning skills: Current research and open questions, 2, pp. 65-80.

Brown, J. S. (2008). How to connect technology and passion in the service of learning. The Chronicle of Higher Education, 55(8).

Davey, G. \& Fuller, A. (2013). Hybrid Qualifications, Institutional Expectations and Youth Transitions: A Case of Swimming with or Against the Tide. Sociological research online, 18, 1. Available at: http://www.socresonline.org.uk/18/1/2.html>10.5153/sro.2876

Deichman-Sørensen, T. (2007). Mot en ny infrastruktur for læring og kontroll. Kvalitetsvurdering i fag- og yrkesopplæringen. Rapport fra evaluering av Nasjonalt kvalitetsvurderingssystem i grunnopplceringen. Oslo: Arbeidsforskningsinstituttet. AFI-rapport 3/2007.

Dweck, C.S. (1986). Motivational processes affecting learning. American psychologist, 41, 10, 1040-1048.

Engeström, Y. \& Toiviainen, H. (2010). Co-configurational design of learning instrumentalities: an activity-theoretical perspective. In S. Ludvigsen, \& R. Säljö (Eds.), Learning across sites. New tools, infrastructures and practices, Oxford: Pergamon.

Eraut, M. (2002). Developing professional knowledge and competence. London: Routledge.

Finch, C., Mulder, M., Attwell, G. \& Streumer, J. (2007). International comparisons of school to work transitions. European education research association journal, 3, 2, pp. 3-15.

Fuller, A., \& Unwin, L. (2010). Can apprenticeship be innovative? Reconceptualising the learning journey in the knowledge economy. In F. Rauner, \& E. Smith (Eds.), Rediscovering apprenticeship. Research findings of the International Network on Innovative Apprenticeship (INAP), Dordrecht: Springer.

Ghefaili, A. (2003). Cognitive Apprenticeship, Technology, and the Contextualization of Learning Environments. Journal of Educational Computing, Design \& Online learning 4.

Grollmann, P., \& Rauner, F. (2007). Exploring innovative apprenticeship: Quality and costs. Education and Training Vol. 49, No. 6, 2007, pp. 431-446. 
Guile, D., \& Okumoto, K. (2008). Developing vocational practice in the jewellery sector through the incubation of a new "project-object". International Journal of Educational Research, 47(4), pp. 252-260.

Hauge, T. E., Lund, A., \& Vestøl, J. M. (2007). Undervisning i endring: IKT, aktivitet, design. Oslo: Abstrakt Forlag.

Havn, V., Kvalsvik Teige, B., Buland, T., Tønseth,C., Finbak, L., Lian, R. og Hybertsen Lysø, I. (2009). Første delrapport for prosjektet Kunnskapsløftet et løft også for fag- og yrkesopplaringen Trondheim: SINTEF rapport A8578

Helms Jørgensen, C. \& Juul, I. (2009). Bedre samspill mellom skolepraktik og ordinær virksomhetspraktik. Undervisningsministeriets centrale analyse og prognosevirksomhed for erhvervsuddannelserne 2009-10.

Høst, H., \& Michelsen, S. (2014). Opplæringskontorenes rolle i kvalitetsarbeidet. In H. Høst (Ed.), Kvalitet i fag-og yrkesopplceringen. Fokus på opplceringen $i$ bedrift. Rapport 3 Forskning på kvalitet i fag- og yrkesopplæringen. Oslo: NIFU Rapport 12/2014.

Høst, H. (Ed.) (2012). Kunnskapsgrunnlag og faglige perspektiver for en studie av kvalitet i fag-og yrkesopplceringen. Rapport 1 Forskning på kvalitet $\mathrm{i}$ fag- og yrkesopplæringen. Oslo: NIFU, FAFO \& HIOA.

Høst, H., Skålholt, A., Nore, H., \& Tønder, A. H. (2012). Gjennomgående dokumentasjon, eller opplceringsboka i ny form? Evaluering av forsøket med gjennomgående dokumentasjon i fag- og yrkesoppleringen. Oslo: NIFU. Rapport 16/2012.

Kirpal, S. (2010). Trainers' changing role and continuing learning in different VET systems: A comparative perspective. In F. Rauner, \& E. Smith (Eds.), Rediscovering apprenticeship. Research findings of the International Network on Innovative Apprenticeship (INAP), Dordrecht: Springer.

MacLean, R., \& Wilson, D. (Eds.) (2009). International handbook of education for the changing world of work. Vol. 2. Springer science business.

Michelsen, S., \& Høst, H. (2013). Nasjonalt system og lokalt arbeid: Om kvalitet i fag- og yrkesopplæringen. In H. Høst (Ed.), Kvalitet $i$ fag- og yrkesopplaringen. Fokus på skoleopplæringen. Rapport 2 Forskning på kvalitet i fag-og yrkesopplceringen. Oslo: NIFU rapport 21/2013.

Onstenk, J. (2010). Coaching and collaborative work-based learning in Dutch VET: The "TEAMstages' Project". In F. Rauner, \& E. Smith (Eds.), Rediscovering apprenticeship. Research findings of the International Network on Innovative Apprenticeship (INAP). Dordrecht: Springer.

Pedró, F. (2006). The new millennium learners: Challenging our view on ICT and learning: OECD-CERI.

Rauner, F., Wittig, W., \& Deitmer, L. (2010). Plural administration in dual systems in selected European countries. In Rediscovering apprenticeship, pp. 31-43, Springer Netherlands.

Rauner, F. \& MacLean, R. (Eds.) (2009). Handbook of technical and vocational education and training research, Heidelberg: Springer.

Tapscott, D (2009). Grown Up Digital: How the Net Generation is changing Your World. New York: McGraw-Hill.

Tuomi-Gröhn, T., Engeström, Y., \& Young, M. (2003). From Transfer to Boundary-crossing between School and Work as a Tool for Developing Vocational Education: An Introduction. In Between school and work: New Perspectives on Transfer and Boundary-crossing. Pp. 1-15. Oxford: Elsevier Science Ltd. 
Veugelers, W., \& O'Hair, M. J. (2005). Network learning for educational change. Maidenhead: Open University Press. 